\title{
HUBUNGAN PERSEPSI MAHASISWA DENGAN KETERAMPILAN DOSEN DALAM MENGELOLA KELAS DAN HASIL BELAJAR
}

\author{
Fatmawati Gaffar \\ Jurusan Pendidikan Luar Sekolah, Fakultas IImu Pendidikan, Universitas Negeri Makassar \\ Email: fatmawatigaffar@unm.ac.id
}

\begin{abstract}
The perception student with skill lecturer in managing classes and study results. This study examines the relationship between student perceptions with lecturer skills in managing classes and student learning outcomes in the year 2018. The purpose of this study was to determine whether or not there was a relationship between students perceptions with lecturer skills in managing classes and student learning outcomes in the year 2018. This type of research is qualitative with a survey desgn. Primary data from the questionnaire with a sample of 54 people, the data were analyzed using Chi Square. The results showed that there was a relationship between students perceptions with lecturer skills in managing classes and student learning outcomes in the year 2018 Keywords: Perception, Managing Classes, Study Results
\end{abstract}

\begin{abstract}
Abstrak
Hubungan Persepsi Mahasiswa dengan Keterampilan Dosen Dalam Mengelola Kelas dan Hasil Belajar. Penelitian ini mengkaji tentang hubungan antara persepsi mahasiswa dengan keterampilan dosen dalam mengelola kelas dan hasil belajar mahasiswa angkatan 2018. Tujuan penelitian ini untuk mengetahui ada atau tidaknya hubungan antara persepsi mahasiswa dengan keterampilan dosen dalam mengelola kelas dan hasil belajar mahasiswa angkatan 2018 Jenis penelitian bersifat kuantitatif dengan desain survey. Data primer dari kuesioner dengan jumlah sampel 54 orang, data dianalisis menggunakan Chi Square. Hasil penelitian menunjukkan bahwa ada hubungan antara persepsi mahasiswa dengan keterampilan dosen dalam mengelola kelas dan hasil belajar mahasiswa angkatan 2018.
\end{abstract}

Kata Kunci: Persepsi, Keterampilan Mengelola Kelas, Hasil Belajar

\section{Pendahuluan}

Peran Perguruan Tinggi untuk menciptakan sumber daya manusia yang berdaya saing tinggi sangat besar pengaruhnya terhadap kemajuan bangsa. Diantara beberapa Perguruan Tinggi ternama yang ada di Indonesia, Universitas Negeri Makassar merupakan salah satu Perguruan Tinggi yang diharapkan mampu menjadi pelopor peradaban yang unggul pada masa yang akan datang.

Universitas Negeri Makassar Fakultas IImu Pendidikan Jurusan Pendidikan Luar Sekolah diharapkan mampu mencetak sumber daya manusia berkualitas yang nantinya akan menjadi ujung tombak bagi kemajuan bangsa. Untuk itu, keterampilan dosen dalam mengajar sangat diperlukan dalam menyampaikan ilmu pengetahuan dan keterampilan agar mahasiswa memiliki kompetensi sesuai dengan tuntutan dunia kerja yang berkembang pesat.
Penerapan keterampilan mengajar secara efektif dapat diukur berdasarkan beberapa indikator seperti kemampuan bertanya, kemampuan memberi penguatan, kemampuan menjelaskan, kemampuan mengadakan variasi, kemampuan membuka dan menutup pelajaran, kemampuan mengelola kelas dan kemampuan membimbing diskusi kelompok kecil serta kemampuan mengajar kelompok dan perorangan dalam setiap proses pembelajaran.

Diantara beberapa keterampilan tersebut, peneliti memilih fokus pada keterampilan mengajar dalam mengelola kelas yang nantinya akan dijadikan sebagai salah satu variabel dalam penelitian. Keterampilan mengelola kelas adalah seperangkat kegiatan untuk mengembangkan tingkah laku peserta didik yang diinginkan, mengulang atau meniadakan tingkah laku yang tidak diinginkan, dengan hubungan-hubungan inter personal dan iklim sosiol emosional yang positif serta mengembangkan dan mempermudah 
Learning Society: Jurnal CSR, Pendidikan dan Pemberdayaan Masyarakat

Jurnal Program Studi Pendidikan Masyarakat

Universitas Mulawarman

Vol. 2 No. 1, Juni 2021. Hal: 58 - 68

organisasi kelas yang efektif. Hal ini menyebabkan pengelolaan kelas menjadi salah satu faktor penting menentukan kinerja dosen dalam proses pembelajaran.

Mencapai hasil belajar yang optimal merupakan sesuatu yang tidak mudah bagi setiap orang. Demikian juga yang dialami oleh mahasiswa. Untuk itu, ada beberapa faktor yang harus diperhatikan oleh pendidik, salah satu diantaranya yang akan dibahas lebih lanjut dalam penelitian ini yaitu keterampilan mengajar yang difokuskan pada keterampilan mengelola kelas. Keterampilan mengelola kelas yang diterapkan oleh dosen atau tenaga pendidik memiliki peranan penting dalam menanamkan pemahaman kepada mahasiswa pada setiap proses belajar mengajar.

Sepanjang tahun 2016, kemenristekdikti telah mampu menunjukan pencapaian kinerja yang memuaskan. Hal ini tercermin melalui peningkatan kualitas dan kuantitas dari komponen dosen kelembagaan perguruan tinggi. Data dosen di indonesia menunjukkan peningkatan dari tahun ke tahun. Pada tahun 2016 jumlah dosen di indonesia meningkat menjadi 237.837 Orang, dari yang sebelumnya 227.734 orang (kemenristekdikti,2016).

Kenyataan dilapangan menunjukkan bahwa faktor keterampilan mengajar khususnya pada segi pengelolaan kelas, belum terasakan secara langsung oleh mahasiswa sebagai sesuatu yang turut mendorong mahasiswa untuk meningkatkan hasil belajar, sementara keterampilan mengajar dosen menjadi salah satu faktor yang dapat berpengaruh pula pada kemampuan mahasiswa dalam meningkatkan hasil belajar secara optimal.

Data yang diperoleh dari kampus Universitas Negeri Makassar tercatat dosen yang mengajar di Jurusan Pendidikan Luar Sekolah sejumlah 10 orang dan mahasiswa Angkatan 2018 sebanyak 54 orang. Dari data tersebut diketahui bahwa persepsi mahasiswa mengenai keterampilan dosen dalam mengelola kelas sangat penting untuk menunjang hasil belajar mahasiswa, dilihat dari kondisi belajar yang terjadi bahwa kondisi belajar mahasiswa dikelas kurang optimal sehingga dapat menimbulkan hasil belajar yang tidak optimal pula dan tidak seperti diharapkan.

Pemberian mata kuliah dengan metode diskusi atau pemberian tugas dengan bimbingan lebih lanjut akan membuat mahasiswa bersikap aktif dalam proses pembelajaran tetapi sebaliknya hal itu dapat memicu semangat untuk belajar dengan serius.

Berdasarkan dengan hal-hal yang telah dikemukakan di atas, menarik untuk mengadakan suatu penelitian terarah dengan judul "Hubungan antara Persepsi Mahasiswa dengan Keterampilan Dosen dalam Mengelola Kelas dan Hasil Belajar Mahasiswa Jurusan Pendidikan Luar Sekolah Angkatan 2018 Fakultas IImu Pendidikan Universitas Negeri Makassar"

\section{Tinjauan Pustaka}

\section{A. Persepsi Mahasiswa}

\section{Pengertian}

Persepsi merupakan sebuah istilah yang sudah sangat familiar didengar dalam percakapan sehari-hari. Istilah persepsi berasal dari bahasa inggris "perception",yang diambil dari bahasa latin "perception", yang berarti menerima atau mengambil, jadi persepsi adalah salah satu aspek kognitif manusia yang sangat penting, yang memungkinkannya untuk mengetahui dan memahami dunia sekelilingnya tanpa persepsi yang benar, manusia mustahil dapat menangkap dan memaknai berbagai fenomena, informasi atau data yang senantiasa mengitarinya (Desmita, 2014:117).

Persepsi merupakan suatu proses yang didahului oleh proses penginderaan yaitu merupakan proses diterimanya stimulus oleh individu melalui alat indra atau juga disebut dengan proses sensoris (Branca, 2014:99).

\section{Faktor-faktor yang berperan dalam persepsi}




\section{a. Objek yang dipersepsikan}

Objek menimbulkan stimulus yang mengenai alat indra atau reseptor. Stimulus dapat datang dari luar individu yang mempersepsi tetapi juga dapat datang dari dalam diri individu yang bersangkutan yang langsung mengenai syaraf penerima yang bekerja sebagai reseptor namun sebagian besar stimulus datang dari luar individu.

b. Alat indera, syaraf, dan pusat susunan syaraf

Alat indra atau reseptor merupakan alat untuk menerima stimulus disamping itu juga harus ada syaraf sensoris sebagai alat untuk meneruskan stimulus yang diterima reseptor ke pusat susunan syaraf yaitu otak sebagai pusat kesadaran, sebagai alat untuk mengadakan respon di perlukan syaraf motoris.

c. Perhatian

Untuk menyadari dan untuk mengadakan persepsi diperlukan adanya perhatian, yaitu merupakan langkah pertama sebagai suatu persiapan dalam rangka mengadakan persepsi. Perhatian merupakan pemusatan atau konsentrasi dari seluruh aktivitas individu yang ditujukan kepada sesuatu atau sekumpulan objek (Walgito, 2010:101)

\section{B. Keterampilan Mengelola Kelas}

\section{Pengertian}

$$
\begin{aligned}
& \text { Keterampilan mengelola kelas } \\
& \text { adalah keterampilan guru untuk } \\
& \text { menciptakan dan memelihara kondisi } \\
& \text { belajar yang optimal dan keterampilan } \\
& \text { untuk mengembalikan kondisi belajar yang } \\
& \text { optimal, apabila terdapat gangguan dalam } \\
& \text { proses belajar baik yang bersifat gangguan } \\
& \text { kecil dan sementara maupun yang bersifat } \\
& \text { gangguan yang berkelanjutan. Apa bila } \\
& \text { terdapat gangguan gangguan dalam } \\
& \text { proses belajar dan guru bertindak untuk } \\
& \text { mengembalikannya ke situasi belajar yang }
\end{aligned}
$$

optimal maka tindakan tersebut termaksud tindakan mendisiplinkan kelas (Abimanyu, 2008:85).

Suatu kondisi belajar yang optimal dapat tercapai bila guru mampu mengatur siswa dan saran pembelajaran serta mengendalikannya dalam suasana yang sangat menyenangkan untuk mencapai tujuan pembelajaran. Hubungan interpersonal antara guru dengan peserta didik, peserta didik sama peserta didik merupakan syarat keberhasilan pengelolaan kelas. Pengelolaan yang efektif merupakan prasyarat bagi terjadinya proses pembelajaran yang efektif.

Keterampilan mengelolah kelas merupakan keterampilan guru untuk menciptakan dan memelihara kondisi belajar yang optimal dan mengembalikan ke kondisi yang optimal jika terjadi gangguan, baik dengan cara mendisiplinkan atau pun melakukan kegiatan remedial (Asril, 2015:72-73).

Mengelola kelas adalah kemampuan guru atau wali kelas dalam mendayagunakan potensi kelas berupa pemberian kesempatanyang seluasluasnya pada setiap personal untuk melakukan kegiatan-kegiatan yang kreatif dan terarah (Sanjaya, 2013:33).

Mengelola kelas adalah suatu usaha yang dilakukan oleh penanggung jawab kegiatan belajar mengajar atau yang membantu dengan maksud agar dicapai kondisi optimal sehingga dapat terlaksana kegiatan belajar seperti yang diharapkan (Sofan dkk, 2013:45).

Dengan demikian dapat disimpulkan bahwa keterampilan mengajar dalam mengelola kelas dapat diartikan sebagai proses menyampaikan dan menanamkan ilmu pengetahuan yang disampaikan oleh guru kepada siswa dengan menggunakan alat pengajaran dan mengatur lingkungan belajar sebagai 
proses menyampaikan, menanamkan ilmu pengetahuan dan karakteritik mengajar sehingga tercipta kondisi belajar yang kondusif.

\section{Rasional mengelola kelas}

Rasional kelas merupakan tempat belajar bagi siswa dan tugas guru sebagian besar terjadi dalam kelas adalah membelajarkan siswa dengan menyediakan kondisi belajar yang optimal.

a. Tugas utama guru membelajarkan siswa. Untuk itu, diperlukan kondisi belajar yang optimal .

b. Belajar berkaitan dengan faktor internal siswa, yaitu: motivasi belajar, minat belajar, kemauan belajar, kemampuan belajar dan lain-lain. Faktor internal ini harus di pertahankan dan dikembangkan melalui pengelolaan kelas.

c. Belajar juga dipengaruhi oleh faktor eksternal, yaitu : kondisi lingkungan kelas, sarana pembelajaran, pengaturan tempat duduk, dan lainlain. Kondisi eksternal itu perlu diatur melalui pengelolaan kelas.

d. Proses belajar siswa yang optimal dapat terganggu oleh faktor internal dan atau faktor eksternal siswa yang tidak menunjang.

e. Oleh karena itu, guru harus mampu mengelola kelas agar siswa dapat belajar secara optimal (Soli Abimanyu,2008:86).

\section{Tujuan mengelola kelas}

Tujuan mengelola kelas adalah agar setiap siswa setiap siswa di kelas dapat dapat belajar dengan tertib sehingga tercapai tujuan pengajaran secara efektif dan efisien.

a. untuk siswa

1) Mendorong siswa mengembangkan kesadaran dan tanggung jawab mengendalikan prilaku belajar dalam kelas.
2) Membantu siswa berprilaku sesuai dengan tata tertib kelas/sekolah, dan menyadari bahwa peringatan dan teguran guru bukan kemarahan.

3) Mengembangkan rasa berkewajiban siswa melaksanakan tugas-tugas belajar dan berprilaku wajar.

b. Untuk guru

1) Mengembangkan pengertian dan keterampilan guru membelajarkan siswa dengan langkah tepat

2) Memiliki kesadaran akan kebutuhan belajar siswa dan mengembangkan kemampuannya (kompetensinya) dalam memberikan pengarahan yang jelas kepada siswa.

3) Merespon secara efektif terhadap tingkah laku siswa yang mengganggu belajarnya, dan menguasai seperangkat strategi yang dapat digunakan untuk menanggulangi gangguan tersebut(Soli Abimanyu, 2008:8687).

\section{Komponen keterampilan mengelola kelas}

Komponen diartikan dengan bagian dari keseluruhan dari unsur sementara keterampilan berasal dari kata kata terampil yang berarti sebagai cakap dalam menyelesaikan tugas jadi komponen keterampilan mengelola kelas adalah keseluruhan kemampuan yang dimiliki oleh guru dalam menyelesaikan tugasnya. Adapun komponen keterampilan mengelola kelas adalah sebagai berikut :

a. Kehangatan dan keantusiasan 
b. Penggunaan bahan yang menantang akan meningkatkan gairah belajar siswa

c. Perlu dipertimbangkan penggunaan variasi media, gaya mengajar, dan pola interaksi

d. Diperlukan keluwesan tingkah laku guru dalam mengubah strategi mengajarnya untuk mencegah gangguan yang timbul

e. Penekanan hal yang positif dan menghindari pemusatan perhatian siswa pada hal negatif

f. Mendorong siswa untuk mengembangkan disiplin diri sendiri dengan cara memberi contoh dalam perbuatan guru sehari-hari (Rusman,2016:89)

\section{Tentang Hasil Belajar}

\section{Pengertian Hasil Belajar}

Belajar adalah kegiatan yang berproses dan merupakan unsur yang sangat fundemental dalam penyelenggaraan setiap jenis dan jenjang pendidikan. Ini berarti bahwa berhasil atau gagalnya pencapaian tujuan pendidikan itu amat bergantung pada proses belajar yang dialami siswa, baik ketika ia berada di sekolah maupun dilingkungan rumah atau keluarganya sendiri (Muhibbin Syah,2015:63).

Belajar adalah suatu proses yang kompleks yang terjadi pada diri setiap orang sepanjang hidupnya. Proses belajar itu terjadi karena adanya interaksi antara seseorang dengan lingkunganya. Oleh karena itu, belajar dapat terjadi kapan saja dan dimana saja. Salah satu pertanda bahwa seseorang itu telah belajar adalah adanya perubahan tingkah laku pada diri orang itu yang mungkin disebabkan oleh terjadinya perubahan pada tingkat pengetahuan,keterampilan, atau sikapnya (Arsyad,2014:2).

Dengan demikian dari beberapa teori diatas maka dapat disimpulkan bahwa hasil belajar adalah prestasi belajar yang dicapai siswa dalam proses kegiatan belajar mengajar dengan membawa suatu perubahan dan pembentukan tingkah laku seseorang untuk menyatakan bahwa suatu proses belajar dapat berhasil.

\section{Ciri-ciri Belajar}

Jika hakikat belajar adalah perubahan tingkah laku, maka ada beberapa perubahan tertentu yang dimasukkan ke dalam ciri-ciri belajar.

a. Perubahan yang terjadi secara sadar

Individu yang belajar akan menyadari terjadinya perubahan itu atau sekurangkurangnya individu merasakan telah terjadi adanya suatu perubahan pada dirinya. Misalnya ia menyadari bahwa pengetahuannya bertambah, kecakapanya bertambah, kebiasaanya bertambah. Jadi, perubahan tingkah laku individu yang terjadi karena mabuk atau dalam keadaan tidak sadar, tidak termaksud kategori perubahan dalam pengertian belajar. Karena individu yang bersangkutan tidak menyadari akan perubahan itu.

b. Perubahan dalam belajar bersifat fungsional

Sebagai hasil belajar, perubahan yang terjadi dalam diri individu berlangsung terus menerus dan tidak statis. Suatu 
perubahan yang terjadi akan menyebabkan perubahan berikutnya dan akan berguna bagi kehidupan ataupun proses belajar berikutnya. Misalnya, jika seorang anak belajar menulis, maka ia akan mengalami perubahan dari tidak menulis menjadi dapat menulis.

c. Perubahan dalam belajar bersifat posittif dan aktif

$$
\text { Dalam perbuatan }
$$

belajar, perubahan-perubahan itu selalu bertambah dan tertuju untuk memperoleh suatu yang lebih baik dari sebelumnya. Dengan demikian, makin banyak usaha belajar dilakukan, makin banyak dan makin baik perubahan yang diperoleh perubahan yang bersifat aktif artinya bahwa perubahan itu tidak terjadi dengan sendirinya, melainkan karena usaha individu sendiri misalnya, perubahan tingkah laku karena proses kematangan yang terjadi dengan sendirinya karena dorongan dari dalam, tidak termaksud perubahan dalam pengertian belajar.

d. Perubahan dalam belajar bukan bersifat sementara

Perubahan yang bersifat sementara (temporer) yang terjadi hanya untuk beberapa saat saja, seperti berkeringat,keluar air mata menangis, dan sebagainya tidak dapat digolongkan sebagai perubahan dalam pengertian belajar. Perubahan yang terjadi karena proses belajar bersifat menetap atau permanen. Ini berarti bahwa tingkah laku yang terjadi setelah belajar akan bersifat menetap. Misalnya kecakapan seorang anak dalam memainkan piano setelah belajar tidak akan hilang, melainkan akan terus dimiliki dan bahkan makin berkembang bila terus dipergunakan atau dilatih.

e. Perubahan dalam belajar bertujuan dan terarah

Perubahan tingkah laku itu terjadi karena ada tujuan yang akan dicapai. Perubahan belajar terarah pada perubahan tingkah laku yang benar-benar disadari. Misalnya seseorang yang belajar mengetik, sebelumnya sudah menetapkan apa yang mungkin dapat dicapai dengan belajar mengetik, atau tingkat kecakapan mana yang akan dicapainya. Dengan demikian perbuatan belajar yang dilakukan senantiasa terarah pada tingkah laku yang telah ditetapkanya.

f. Perubahan yang mencakup seluruh aspek tingkah laku Perubahan yang diperoleh individu setelah melalui suatu proses belajar meliputi perubahan keseluruhan tingkah laku. Jika seseorang belajar sesuatu, sebagai hasilnya ia akan mengalami perubahan tingkah laku secara menyeluruh dalam sikap kebiasaan keterampilan, pengetahuan, dan sebagainya. Misalnya, jika seorang anak telah belajar naik sepeda, maka perubahanya yang paling tampak adalah dalam keterampilan naik sepeda itu. 


\section{METODE PENELITIAN}

Akan tetapi, ia telah mengalami perubahan-perubahan lainya seperti pemahaman tentang cara kerja sepeda (Djamarah, 2011:15-16).

\section{A. Jenis Penelitian dan Pendekatan}

Jenis penelitian yang dilakukan merupakan penelitian yang bersifat kuantitatif yaitu penelitian ilmiah yang sistematis terhadap bagian-bagian dan fenomena serta hubunganhubungannya, dengan pendekatan survey yaitu bertujuan untuk mengumpulkan informasi tentang orang yang jumlah besar, baik itu menggunakan angket, kuesioner, atau wawancara.

\section{B. Populasi Penelitian}

Populasi adalah keseluruhan dari objek penelitian atau objek yang diteliti atau setiap subjek yang memenuhi kriteria yang telah ditetapkan. Populasi dalam penelitian adalah mahasiswa angkatan 2018 Jurusan Pendidikan Luar Sekolah Fakultas IImu Pendidikan Universitas Negeri Makassar

\section{Metode Pengumpulan Data}

Dalam penelitian ini metode pengumpulan data yang digunakan adalah data primer, data yang diperoleh melalui kuesioner.

D. Analisa Data

Setelah data diolah kemudian dianalisa dengan menggunakan bantuan computer dengan program SPSS 22 adapun analisa data yang digunakan yaitu 1. Analisa Univariat

Analisa univariat dilakukan terhadap setiap variabel dari hasil penelitian, analisa ini akan menghasilkan distribusi dan presentase dari setiap variabel yang diteliti.

$$
P=\frac{f}{n} \times 100 \%
$$

Keterangan

$\mathrm{P}=$ Persentase $f=$ frekuensi sampel

$\mathrm{n}=$ frekuensi seluruh observasi (Sudijono, 2014)

2. Analisa Bivariat

Analisa Bivariat dilakukan untuk melihat hubungan tiap tiap variabel bebas dan terikat dengan menggunakan uji statistic chi-square $\left(\mathrm{x}^{2}\right)$ dengan tingkat kemaknaan $(\alpha=0,05)$.

Dari hasil uji statistik tersebut dapat diketahui tingkat signifikan hubungan antara kedua variabel tersebut jika nilai signifikan $<0,05$ maka hipotesis alternatif $(\mathrm{Ha})$ diterima, dan jika nilai signifikan $>0,05$ maka hipotesis nol $(\mathrm{HO})$ diterima.

\section{HASIL DAN PEMBAHASAN}

\section{A. Hasil}

Penelitian Mengenai hubungan antara persepsi mahasiswa dengan keterampilan dosen dalam mengelola kelas dan hasil belajar mahasiswa Angkatan 2018 Jurusan Pendidikan Luar Sekolah Fakultas IImu Pendidikan Universitas Negeri Makassar melalui penelitian kuantitatif dengan pendekatan "Study Survey".

Penelitian ini dilakukan di Jurusan Pendidikan Luar Sekolah Fakultas IImu Pendidikan Universitas Negeri Makassar karena ditinjau dari banyaknya persepsi mahasiswa yang beragam mengenai keterampilan dosen dalam mengelola kelas saat proses pembelajaran berlangsung dan dampak dari persepsi tersebut membuat hasil belajar mahasiswa beragam pula ada yang baik dan ada yang kurang. Dengan demikian, setiap dosen dituntut untuk dapat menerapkan keterampilan mengajar secara efektif.

. Data yang telah dikumpulkan diperiksa kelengkapannya, kemudian dimasukkan ke dalam fasilitas pengolahan data yang menggunakan program spss 22 hasilnya diuraikan secara sistematis sebagai berikut:

1. Analisis Univariat

a. Distribusi frekuensi tentang keterampilan dalam mengelola kelas 
Learning Society: Jurnal CSR, Pendidikan dan Pemberdayaan Masyarakat

Jurnal Program Studi Pendidikan Masyarakat

Universitas Mulawarman

Vol. 2 No. 1, Juni 2021. Hal: 58 - 68

Tabel. 1. Distribusi Frekuensi Tentang Keterampilan dalam Mengelola Kelas

\begin{tabular}{|c|c|c|}
\hline Keterampilan mengelola kelas & F & $(\%)$ \\
\hline Baik & 37 & 68,5 \\
Kurang & 17 & 31,5 \\
\hline Total & 54 & 100 \\
\hline
\end{tabular}

Sumber : Data primer Tahun 2019

Berdasarkan pada tabel di atas dari 54 responden, terdapat $37(68,5 \%)$ mahasiswa yang menyatakan baik tentang keterampilan dosen dalam mengelola kelas dan mahasiswa yang menyatakan kurang terdapat $17(31,5 \%)$.

Dengan demikian dapat kita ketahui bahwa keterampilan dosen dalam mengelola

Tabel 2. Distribusi frekuensi tentang hasil belajar mahasiswa mahasiswa angkatan 2018

\begin{tabular}{|c|c|c|}
\hline Hasil belajar & Frekuensi & $\%$ \\
\hline Baik & 42 & 77,8 \\
Kurang & 12 & 22,2 \\
\hline Total & 54 & 100 \\
\hline
\end{tabular}

Sumber : Data primer Tahun 2019

Berdasaran tabel diatas dari 54 responden terdapat $42(77,8 \%)$ mahasiswa dengan hasil belajar yang berada pada kategori baik, dan $12(22,2 \%)$ pada kategori kurang. Dengan demikian dapat kita ketahui

kelas di Jurusan Pendidikan Luar Sekolah Fakultas IImu Pendidikan Universitas Negeri Makassar yaitu dalam kategori baik.

b. Distribusi Frekuensi tentang hasil belajar

Tabel 3 Distribusi persepsi mahasiswa

\begin{tabular}{|c|c|c|}
\hline Persepsi & Frekuensi & $\%$ \\
\hline Baik & 42 & 77,8 \\
Kurang & 12 & 22,2 \\
\hline Total & 54 & 100 \\
\hline
\end{tabular}

Sumber :Data primer Tahun 2019

Berdasaran tabel diatas dari 54 responden terdapat $42(77,8 \%)$ mahasiswa dengan persepsi berada pada kategori baik, dan $12(22,2 \%)$ pada kategori kurang. Dengan demikian dapat kita ketahui bahwa persepsi mahasiswa dalam kategori baik.

bahwa hasil belajar mahasiswa dalam kategori baik .

c. Distribusi frekuensi tentang persepsi

2. Analisis Bivariat

Analisis ini dilakukan untuk melihat adanya hubungan antara variabel dependen dengan variabel independen yang dianggap mempunyai peran terhadap variabel dependen menggunakan tabulasi silang (2x2), sebagaimana yang diuraikan pada tabel dibawah ini:

a. Hubungan Persepsi Mahasiswa dengan

Keterampilan Dosen Dalam Mengelola Kelas

\begin{tabular}{|c|c|c|c|c|c|c|c|}
\hline \multirow{3}{*}{$\begin{array}{l}\text { Keterampilan dalam mengelola } \\
\text { kelas }\end{array}$} & \multicolumn{4}{|c|}{ Persepsi } & \multirow{2}{*}{\multicolumn{2}{|c|}{ Jumlah }} & \multirow{3}{*}{$a=0.05$} \\
\hline & \multicolumn{2}{|c|}{ Baik } & \multicolumn{2}{|c|}{ Kurang } & & & \\
\hline & $\mathrm{F}$ & $\%$ & $\mathrm{~F}$ & $\%$ & $\mathrm{~F}$ & $\%$ & \\
\hline
\end{tabular}


Learning Society: Jurnal CSR, Pendidikan dan Pemberdayaan Masyarakat

Jurnal Program Studi Pendidikan Masyarakat

Universitas Mulawarman

Vol. 2 No. 1, Juni 2021. Hal: 58 - 68

\begin{tabular}{|c|c|c|c|c|c|c|c|}
\hline Baik & 34 & 63,0 & 3 & 5,6 & 37 & 68,5 & \\
& 8 & 14,8 & 9 & 16,7 & 17 & 31,5 & \multirow{2}{*}{$\mathrm{P}=0.001$} \\
& & & & & & & \\
\hline kurang & 42 & 77,8 & 12 & 22,2 & 54 & 100 & \\
\hline
\end{tabular}

Sumber : Data Primer Tahun 2019

Berdasarkan tabel diatas menunjukkan dari 54 mahasiswa yang memiliki persepsi dengan keterampilan dosen dalam mengelola kelas pada kategori baik terdapat 34 atau $63,0 \%$ dan 3 atau $5,6 \%$ yang tidak memiliki persepsi. Data lainnya terlihat pada mahasiswa yang memiliki persepsi dengan keterampilan dosen dalam mengelola kelas pada kategori kurang diperoleh 8 atau 14,8 sedangkan yang memiliki persepsi baik 9 atau $16,7 \%$.

Uji statistik dengan crosstab chi-square didapatkan nilai $p=0.001<a=0.05$, yang menunjukkan Ha diterima artinya ada hubungan yang signifikan antara persepsi mahasiswa dengan keterampilan dosen dalam mengelola kelas.

Berdasarkan data tersebut di atas bahwa dapat di ketahui ada hubungan antara persepsi mahasiswa dengan keterampilan dosen dalam mengelola kelas. Hal ini di dasarkan karena keterampilan dosen dalam mengelola kelas sangatlah penting, keterampilan mengelolah kelas merupakan keterampilan guru untuk menciptakan dan memelihara kondisi belajar yang optimal dan keterampilan untuk mengembalikan kondisi belajar yang optimal, apa bila terdapat gangguan dalam proses belajar baik yang bersifat gangguan kecil dan sementara maupun yang bersifat gangguan yang berkelanjutan.

\section{b. Hubungan Persepsi Mahasiswa Dengan Hasil Belajar \\ Sumber : Data Primer Tahun 2019}

Berdasarkan tabel di atas menunjukkan dari 54 mahasiswa yang memiliki persepsi dengan hasil belajar pada kategori baik terdapat 37 atau $68,5 \%$ dan 5 atau $9,3 \%$ yang tidak memiliki

persepsi. Data lainnya terlihat pada mahasiswa yang memiliki persepsi dengan hasil belajar kurang diperoleh 5 atau 9,3\% sedangkan yang memiliki persepsi baik memperoleh 7 atau 13,0\%.

Uji statistik dengan crosstab chi-square didapatkan nilai $p=0.002<a=0.05$, yang menunjukkan $\mathrm{Ha}$ diterima artinya ada hubungan yang signifikan antara persepsi mahasiswa

\begin{tabular}{|c|c|c|c|c|c|c|c|}
\hline \multirow{3}{*}{$\begin{array}{l}\text { Hasil } \\
\text { belajar }\end{array}$} & \multicolumn{4}{|c|}{ Persepsi } & \multirow{2}{*}{\multicolumn{2}{|c|}{ Jumlah }} & \multirow{3}{*}{$a=0.05$} \\
\hline & \multicolumn{2}{|c|}{ Baik } & \multicolumn{2}{|c|}{ Kurang } & & & \\
\hline & $F$ & $\%$ & $F$ & $\%$ & $F$ & $\%$ & \\
\hline Baik & 37 & 68,5 & 5 & 9,3 & 42 & 77,8 & \\
\hline Kurang & 5 & 9,3 & 7 & 13,0 & 12 & 22,2 & \\
\hline Total & 42 & 77,8 & 12 & 22,2 & 54 & 100 & \\
\hline
\end{tabular}

dengan hasil belajar.

Berdasarkan data tersebut di atas, maka dapat di ketahui ada hubungan antara persepsi mahasiswa dengan Hasil belajar, hal ini di dasarkan karena Belajar adalah suatu proses yang kompleks yang terjadi pada diri setiap orang sepanjang hidupnya. Proses belajar itu terjadi karena adanya interaksi antara seseorang dengan lingkunganya. Oleh karena itu, belajar dapat terjadi kapan saja dan dimana saja. Salah satu pertanda bahwa seseorang itu telah belajar adalah adanya perubahan tingkah laku pada diri orang itu yang mungkin disebabkan oleh terjadinya perubahan pada tingkat pengetahuan, keterampilan, atau sikapnya.

\section{Pembahasan}

Penelitian tentang Hubungan Antara Persepsi Mahasiswa dengan Keterampilan Dosen 
Learning Society: Jurnal CSR, Pendidikan dan Pemberdayaan Masyarakat

Jurnal Program Studi Pendidikan Masyarakat

Universitas Mulawarman

Vol. 2 No. 1, Juni 2021. Hal: 58 - 68

Dalam Mengelola Kelas dan Hasil Belajar Mahasiswa Angkatan 2018 Jurusan Pendidikan Luar Sekolah Fakultas IImu Pendidikan Universitas Negeri Makassar, yang dianalisis berdasarkan variabel yang telah diteliti ternyata cukup bervariasi hal ini dapat dilihat pada pembahasan berikut:

1. Keterampilan mengelola kelas

Keterampilan mengelola kelas merupakan keterampilan guru dalam mengembalikan kondisi belajar yang optimal. Berdasarkan hasil penelitian yang menyatakan ada hubungan antara persepsi mahasiswa dengan keterampilan dosen dalam mengelola kelas, maka peneliti menarik kesimpulan bahwa keterampilan dosen dalam mengelola kelas sangatlah penting, karena dapat membuat peserta didik dapat belajar dengan optimal.

Keterampilan mengelolah kelas merupakan keterampilan guru untuk menciptakan dan memelihara kondisi belajar yang optimal dan mengembalikan ke kondisi yang optimal jika terjadi gangguan, baik dengan cara mendisiplinkan atau pun melakukan kegiatan remedial (Asril, 2015:72-73).

Hal ini sesuai konsep dasar yang menjelaskan bahwa Keterampilan dasar dalam mengajar siswa sangat diperlukan oleh guru agar interaksi antara guru dan siswa bisa berjalan dengan baik dan siswa tidak merasa tertekan saat belajar sehingga pelajaran dapat ditangkap secara maksimal. Keberhasilan seorang guru dalam mengajar tidak hanya ditentukan oleh faktor-faktor yang berhubungan dengan proses pembelajaran saja, melainkan juga ditentukan oleh keterampilan pengelolaan kelas yang dikuasainya. Keterampilan mengelola kelas adalah keterampilan guru untuk menciptakan dan memelihara kondisi belajar yang optimal dan keterampilan untuk mengembalikan kondisi belajar yang optimal.

Dengan demikian dapat di simpulkan bahwa Makin baik keterampilan dosen dalam mengelola kelas maka akan semakin baik pula persepsi mahasiswa mengenai keterampilan dosen dalam mengelola kelas tersebut, sebaliknya semakin kurang keterampilan dosen dalam mengelola kelas maka semakin tidak baik pula persepsi mahasiswa mengenai keterampilan dosen dalam mengelola kelas tersebut.

2. Hasil belajar

Hasil belajar adalah prestasi belajar yang dicapai siswa dalam proses kegiatan belajar mengajar dengan membawa suatu perubahan dan pembentukan tingkah laku seseorang untuk menyatakan bahwa suatu proses belajar dapat berhasil. Berdasarkan hasil penelitian di atas yang menyatakan adanya hubungan antara persepsi mahasiswa dengan hasil belajar mahasiswa maka peneliti dapat menyimpulkan bahwa salah satu tercapainya hasil belajar adanya persepsi yang baik dari diri seseorang mengenai pentingnya belajar tersebut.

Belajar adalah kegiatan yang berproses dan merupakan unsur yang sangat fundemental dalam penyelenggaraan setiap jenis dan jenjang pendidikan. Ini berarti bahwa berhasil atau gagalnya pencapaian tujuan pendidikan itu amat bergantung pada proses belajar yang dialami siswa, baik ketika ia berada di sekolah maupun dilingkungan rumah atau keluarganya sendiri (Syah,2015:63).

Hal ini berdasarkan konsep dasar yang menjelaskan bahwa hasil belajar adalah tingkat pernyataan yang dicapai oleh siswa dalam mengikuti program pembelajaran sesuai dengan tujuan pendidikan yang ditetapkan. Karenanya, hasil belajar siswa mencakup tiga aspek, yaitu : aspek kognitif, aspek afektif, dan aspek psikomotorik.

Demikian dapat di simpulkan bahwa peneliti berasumsi hasil belajar dengan persepsi mahasiswa sangat berhubungan dikarenakan hasil belajar dapat tercapai dengan baik ketika peserta didik tersebut mempunyai persepsi baik pula terhadap suatu proses pembelajaran tersebut sehingga dapat tercapai hasil belajar yang baik, yang seperti di inginkan dan harapkan. Kesimpulan 
Learning Society: Jurnal CSR, Pendidikan dan Pemberdayaan Masyarakat

Jurnal Program Studi Pendidikan Masyarakat

Universitas Mulawarman

Vol. 2 No. 1, Juni 2021. Hal: 58 - 68

Penelitian tentang hubungan antara persepsi mahasiswa dengan keterampilan dosen dalam mengelola kelas dan hasil belajar mahasiswa angkatan 2018 Jurusan Pendidikan Luar Sekolah Fakultas IImu Pendidikan Universitas Negeri Makassar, maka akan disimpulkan sebagai berikut :

1. Ada hubungan antara persepsi mahasiswa dengan keterampilan dosen dalam mengelola kelas di Jurusan Pendidikan Luar Sekolah Fakultas IImu Pendidikan Universitas Negeri Makassar.

2. Ada hubungan antara persepsi mahasiswa dengan hasil belajar mahasiswa Angkatan 2018 Jurusan Pendidikan Luar Sekolah Fakultas IImu Pendidikan Universitas Negeri Makassar

3. Terdapat hubungan antara persepsi mahasiswa dengan keterampilan dosen dalam mengelola kelas dan hasil belajar mahasiswa angkatan 2018 Jurusan Pendidikan Luar Sekolah Fakultas IImu Pendidikan Universitas Negeri Makassar.

\section{DAFTAR PUSTAKA}

Abimanyu, Soli. (2008). Pengajaran Mikro. Makassar: Badan Penerbit UNM.

Arsyad Azhar. (2014). Media Pembelajaran. Jakarta: Rajawali Pers.

Asril, Zailnal. (2015). Micro Teaching Edisi 2. Jakarta: Rajawali Pers.

Djamarah, S. B. (2011). Psikologi Belajar. Jakarta: Rineka Cipta.

Branca. (2014). Psikologi Perkembangan Peserta Didik. Bandung: Remaja Rosdakarya.

Desmita. 2014. Psikologi Perkembangan Peserta Didik Edisi 5. Bandung: Remaja Rosdakarya.
Rusman. 2016. Model-Model Pembelajaran. Jakarta: Rajawali Pers.

Khodijah, Nyanyu. 2016. Psikologi Pendidikan. Jakarta: Rajawali Pers.

Muhibbin, Syah. 2015. Psikologi Pendidikan. Jakarta: Rajawali Pers.

Sanjaya, Wina. 2013. Strategi Pembelajaran Berorientasi Standar Proses Pendidikan. Jakarta: Kencana Prenadamedia Group.

Walgito, Bimo. 2010.Psikologi Pendidikan. Yogyakarta: Andi Offset. 